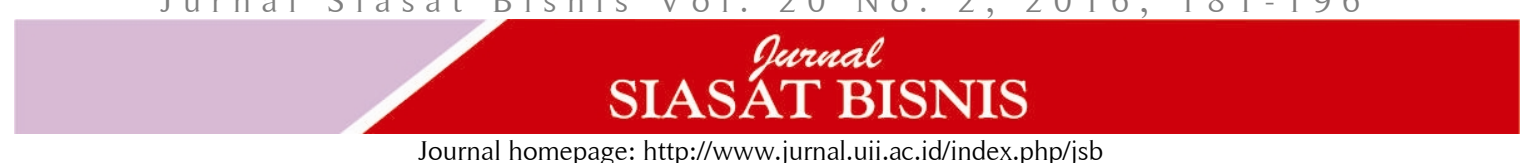

\title{
Faktor Demografis, Personality Traits, dan Overconfidence (Survey terhadap Investor Saham di Yogyakarta)
}

\author{
Liring Dwi Utami ${ }^{1}$, Kartini $^{*}$ \\ 1,2 Jurusan Manajemen, Fakultas Ekonomi, Universitas Islam Indonesia \\ Correspondence author Email: kartiniafif1@gmail.com
}

\begin{abstract}
This study aims to analyze the relationship between demographic faktors, personality traits and overconfidence of retail investors in Yogyakarta. Demographic faktors was operationalized using gender, age, education and investment experience while personality traits was operationalized using the big five personality model. This study used a questionnaire distributed to 100 randomly selected investors. 87 questionnaires were used, while the rest was excluded because of incomplete answers to the questionnaire. The data were processed using SPSS with Chi Square and Pearson Correlation as the statistical tests. The results found that all the demographic faktors, age, gender, education and investment experience had no correlation with overconfidence. Moreover, positif correlation between conscientiousness with overconfidence was found. Whereas extraversion, agreeableness, neuroticism and openness to experience were not related to overconfidence.
\end{abstract}

Keywords: overconfidence bias, demographic faktors, personality traits, investors in yogyakarta

\begin{abstract}
Abstrak
Penelitian ini bertujuan untuk mengetahui hubungan antara faktor demografis, personality traits dan overconfidence pada investor saham di Yogyakarta. Faktor demografi yang digunakan berupa jenis kelamin, usia, pendidikan dan lama investasi sedangkan personality traits menggunakan the big-five personality. Penelitian ini menggunakan kuesioner yang disebar kepada 100 orang investor yang dipilih secara random. Sebanyak 87 kuesioner digunakan sedangkan 13 lainnya didiskualifikasi karena jawaban kuesioner yang tidak lengkap. Data diolah menggunakan SPPS dengan alat ukur Chi Square dan Pearson Correlation. Hasil dari penelitian menemukan bahwa semua faktor demografi yaitu usia, jenis kelamin, pendidikan dan lama investasi tidak mempunyai hubungan dengan overconfidence. Hasil lain menunjukkan adanya hubungan yang positif antara conscientiousness dengan overconfidence. Sedangkan extraversion, agreeableness, neuroticism dan openness to experience tidak mempunyai hubungan dengan overconfidence.
\end{abstract}

Kata Kunci: overconfidence, faktor demografis, personality traits, investor saham yogyakarta

JEL: G00, G02, G11, G14

DOI: 10.20885/jsb.vol20.iss2.art6

\section{Pendahuluan}

Teori keuangan tradisional mengasumsikan bahwa para investor adalah rasional. Investor digambarkan memiliki kemampuan mengidentifikasi dan mengolah informasi secara tepat. Namun pada kenyataannya banyak investor di pasar modal yang berperilaku tidak rasional dengan melakukan tindakan berdasarkan juggement yang jauh dari asumsi rasional (Trinugroho dan Sembel 2011). Ritter (2003) hasil penelitiannya juga mengungkapkan bahwa investor di Jepang, Taiwan, dan Amerika Serikat telah kehilangan uang dalam jumlah yang besar dalam trading karena perilaku mereka yang irasional padahal harga saham pada saat itu mengalami overvalue. Fraser (2003) juga menunjukkan bahwa investor memiliki ekspektasi yang bias yang jauh dari asumsi rasional. Barberis dan Thaler (2003) mengemukakan bahwa investor di Amerika dalam melakukan trading di bursa saham dipengaruhi faktor- faktor psikologi. Odean (2002) hasill penelitiannya menyatakan investor cenderung overconfidence dalam memilih saham, hasil ini 
ditemukan dalam volume perdagangan saham yang tinggi. Fischhoff et al. (1977) mengungkapkan bahwa, ketika orang dihadapkan pada ketidakpastian, mereka cenderung mengambil keputusan yang overconfidence. Begitu juga hasil penelitian Iramani dan Dyka (2008) menunjukkan bahwa ada 6 faktor yang mempengaruhi investor Indonesia dalam melakukan transaksi saham diantaranya faktor overconvidence.

Dari hasil penelitian sebelumnya ditemukan bahwa overconfidence dipengaruhi oleh faktor-faktor tertentu. Diantara faktor-faktor tersebut adalah faktor demografi dan Personality traits. Faktor-faktor ini memerankan peran penting dalam menentukan perilaku investor dan berbagai bias perilaku yang cenderung mereka lakukan. Warren et al. (1990) menyatakan bahwa pilihan investasi seseorang lebih berdasar pada gaya hidup dan karakteristik demografinya. Faktor demografi investor seperti jenis kelamin, usia, pendidikan, dan lama investasi diperkirakan akan mempengaruhi overconfidence investor. Jain dan Mandot (2012) serta Barber dan Odean (2001) hasil penelitiannya menyimpulkan bahwa pria lebih berani dalam mengambil produk investasi yang berisiko tinggi, karena pria cenderung overconfidence dari pada wanita. Begitu juga hasil penelitian Bhandari dan Deaves (2006) bahwa investor pria cenderung overconfidence dalam berinvestasi daripada investor wanita. Hasil penelitian Marie, at al (2007) juga menyimpulkan bahwa kaum wanita cenderung lebih menghindari resiko daripada kaum pria, karena kaum wanita cenderung kurang confidence.

Disamping faktor jenis kelamin, usia dan pendididikan investor juga diperkirakan mempengaruhi investor dalam berinvestasi. Investor dengan usia muda dalam membuat keputusan investasi sangat mempertimbangkan variabel-variabel terkait keputusan investastinya karena pada usia ini masih belum memiliki banyak pengalaman. Investor yang usianya matang tidak banyak mempertimbangkan variabel-variabel investasi dalam kegiatan investasinya karena pada usia ini pengalaman telah banyak didapat sehingga dalam mengambil keputusan investasi lebih pada logika (Christanti dan Mahastanti, 2011). Hasil ini didukung oleh penelitian Lin (2011), Jamshidinavid et al, (2012), dan Bhandari dan Deaves (2006) bahwa investor yang berpendidikan melakukan investasi berdasarkan pengetahuan, kemampuan dan kepercayaan diri mereka sendiri. Heath dan Tversky (1991) menyatakan semakin tinggi tingkat pendidikan akan meningkatkan level kepercayaan diri karena semakin tinggi pendidikan membuat seorang investor merasa lebih kompeten dalam hampir semua bidang termasuk keuangan, hal ini berarti semakin tinggi pendidikan investor semakin rentan overconfidence.

Frekuensi investasi juga diduga berhubungan dengan keputusan investasi. Investor yang masih baru dalam berinvestasi sangat mempertimbangkan semua faktor yang berhubungan dengan keputusan investastinya. Sedangkan semakin lama seorang investor melakukan investasi maka semakin berkurang faktor yang dipertimbangkan sebab semakin lama semakin banyak pengalaman sehingga keputusan investasi lebih banyak berdasarkan pengalaman. Studi yang dilakukan oleh Glaser et al. (2005) menemukan bahwa professional traders biasanya memiliki tingkat overconfidence yang lebih tinggi dibandingkan dengan mahasiswa. Didukung oleh penelitian Alrabadi et al, (2011) bahwa confidence investor meningkat ketika mendapatkan lebih banyak pengalaman

Disamping faktor demografi, overconvidence juga dipengaruhi oleh faktor kepribadian. Kepribadian dalam penelitian ini dilihat berdasarkan The Big five Personality yang dikembangkan oleh McCrae. Karakteristik kelima trait dalam pendekatan Big Five adalah extraversion, agreeableness, conscientiousness, neuroticism serta openness (Costa \& McCrae, 1996). Beberapa hasil penelitian yang menunjukkan adanya hubungan faktor overconvidence dengan personality traits adalah Bhasir et al (2013), Zaidi dan Tauni (2012), Lin (2011), Schaefer et al (2004), dan Jamshidinavid et al (2012). Hasil penelitian mereka menunjukkan bahwa ada hubungan antara personality traits dengan overconfidence. Investor yang mempunyai sifat agreebleness yang tinggi cenderung lebih mudah percaya pada informasi pasar yang ada sehingga akan menimbulkan kepercayaan diri yang berlebih (Zaidi dan Tauni, 2012). Lin (2011), Bashir et al (2013),dan 
Schaefer et al, (2004), menyebutkan bahwa investor dengan trait conscientiousness yang tinggi cenderung percaya pada kinerja mereka sendiri dalam berinvestasi dan merasa lebih baik daripada investor lainnya. Sifat dari openness to experience yang penasaran dan suka mencari informasi baru membuat investor dengan trait ini seringnya melakukan transaksi menjual dan membeli saham yang disebabkan oleh kepercayaan diri yang tinggi (Odean.T, 1999). Dari sini terlihat bahwa openness to experience rentan untuk bersikap overconfidence dalam investasi. Hal ini didukung oleh hasil penelitian Lin (2011) serta Zaidi dan Tauni (2012) yang menemukan adanya hubungan positif antara openness to experience dengan overconfidence.

Pasar modal Indonesia yang dikatagorikan emerging market tentunya beranggotakan banyak pelaku pasar yang masih belajar, begitu juga di Yogyakarta. Kepala Kantor Perwakilan Bursa Efek Indonesia DIY Irfan Noor Riza mengatakan bahwa pertumbuhan investor pasar modal di DIY setiap bulannya mencapai 100 sampai 300 orang dan 30\% diantaranya merupakan mahasiswa. Irfan lebih lanjut mengatakan bahwa ada 150 investor DIY yang investasinya tersangkut di saham tidur, hal ini terjadi karena investor asal pilih perusahaan, mereka tidak memeriksa dulu perusahaan yang mau di beli sahamnya (harianjogja. Com). Ini mengindikasikan bahwa walaupun mereka masih kurang dalam literasi keuangan khususnya mengenahi investasi saham tetapi mereka berani mengambil investasi di saham. Hal ini menunjukkan bahwa investor di DIY kebanyakan overconvidence dalam mengambil keputusan investasi. Bhandari dan Deaves (2006) overconfidence merupakan kecenderungan orang menaksir terlalu tinggi pengetahuan, kemampuan dan ketepatan tentang informasi yang mereka miliki.

\section{Kajian Pustaka}

\section{Bias Overconfidence dalam Perilaku Investasi}

Fenomena overconfidence merupakan kecenderungan pengambil keputusan tanpa disadari untuk memberi bobot penilaian yang berlebihan pada pengetahuan dan akurasi informasi yang dimiliki serta mengabaikan informasi publik yang tersedia (Lichtenstein dan Fischhoff, 1977). Gervais dan Odean (2001) menyatakan bahwa overconfidence adalah distribusi probabilitas prediksi seseorang lebih tinggi dari kenyataannya. Sedangkan Bhandari dan Deaves (2006) overconfidence merupakan kecenderungan orang menaksir terlalu tinggi pengetahuan, kemampuan dan ketepatan tentang informasi yang mereka miliki. Hampir semua temuan psikologi menyimpulkan bahwa perilaku overconfidence cenderung mendorong pengambil keputusan untuk menentukan prediksi dengan tidak akurat sehingga menghasilkan kesalahan prediksi yang lebih tinggi dibandingkan dengan mereka yang lebih rasional. Kesimpulan ini mengkonfirmasi Teori Penipuan Diri (Self Deception Theory) yang dikembangkan oleh Trivers (2000). Teori Trivers ini menjelaskan bahwa ketika pengambil keputusan secara tidak sadar mempersepsikan diri mereka memiliki kapabilitas diatas rata-rata, pola pikir akan menuntun mereka untuk mengelola persepsi mereka dengan cara mencari informasi atau argumentasi lain untuk mendukung perilaku mereka atau mengabaikan informasi yang berlawanan dengan perilaku mereka sendiri. Pada situasi seperti ini, pengambil keputusan mengikuti kebenaran keyakinannya sedemikian rupa sehingga mengarahkannya untuk berperilaku overconfidence.

Overconfidence yang tertanam dalam pikiran investor berimplikasi terhadap perilaku mereka ketika berinvestasi. Seorang investor yang baru melakukan dua-tiga kali transaksi tidak jarang sudah merasa cukup yakin dalam membuat berbagai keputusan investasi. Bila investor di pasar modal yang memiliki perilaku overconfidence ini cukup banyak, maka secara agregat reaksi yang terjadi di pasar akan jauh dari rasional. Pompian (2006) mengatakan kesalahan yang sering muncul akibat dari perilaku overconfidence adalah yang pertama overconfidence menyebabkan investor melakukan perdagangan yang berlebihan karena keyakinan memiliki pengetahuan khusus yang sebenarnya tidak dimiliki. Kedua, overconfidence menyebabkan investor menjadi overestimate dalam mengevaluasi investasi. Ketiga, overconfidence 
menyebabkan investor menjadi underestimate terhadap adanya risiko. Keempat, overconfidence menyebabkan investor tidak melakukan diversifikasi portofolio investasinya.

Bhasir et al (2013) melakukan penelitian mengenai pengaruh karakteristik demografi dan personality traits terhadap overconfidence. Penelitian ini mengukur faktor overconfidence pada karyawan dan faktor overconfidence pada mahasiswa. Hasil penelitian menemukan bahwa karyawan ketika pengalamannya banyak level overconfidence nya menurun. Dalam penelitian ini juga menunjukkan bahwa semua faktor personality traits (conscientiousness, agreeableness, emotional stability dan openness to experience) mempunyai hubungan dengan overconfidence. Pada mahasiswa tidak terdapat korelasi antara personality traits dengan overconfidence. Menurut penelitian karyawan lebih rentan terhadap overconfidence karena karyawan menghasilkan uang sendiri, mempunya sumber daya lebih banyak sehingga mereka melakukan investasi yang lebih banyak. Sehingga personality traits mereka berkembang akhirnya dapat mempengaruhi level convidence mereka.

Zaidi dan Tauni (2012) menguji pengaruh antara personality traits dan faktor demografi terhadap overconfidence pada Lahore Stock Exchange (LSE) kepada 200 responden. Hasilnya menunjukkan bahwa ada hubungan yang positif antara overconfidence dengan agreeableness, extraversion dan conscientiousness dan hubungan negatif antara overconfidence dan neuroticism. Hasil lainnya juga menunjukkan bahwa ada hubungan antara pengalaman investasi dan bias overconfidence. Hasil ini menunjukkan bahwa investor dalam LSE tidak sepenuhnya rasional dan penjelasan mengenai teori keuangan tradisional tidak sepenuhnya benar.

Lin (2011) dalam penelitiannya menguji pengaruh faktor demografi dan psychological traits pada bias investasi. Personality traits menggunakan big five model untuk menguji hubungan personality traits investor dan behavioral biases. Peneliti menemukan bahwa empat personality traits dan tiga faktor demografi secara signifikan mempengaruhi tiga bias perilaku dalam investasi yaitu disposition effect, overconfidence, dan herding. Peneliti menemukan bahwa neuroticism mempunyai hubungan yang positif dengan diposition effect dan herding sementara neuroticism tidak mempunyai hubungan dengan overconfidence. Extraversion, openness to experience dan conscientiousness mempunyai hubungan yang positif dengan disposition effect dan overconfidence sementara extraversion tidak mempunyai hubungan dengan herding. Selain itu peneliti juga menemukan adanya hubungan negatif antara gender dan overconfidence yang berarti laki-laki lebih overconfidence daripada perempuan. Usia mempunyai hubungan yang positif dengan disposition effect dan overconfidence. Dan terdapat hubungan yang positif antara area tempat tinggal dengan herding.

Jamshidinavid et al. (2012) melakukan penelitian untuk menguji hubungan faktor demografi dan karakteristik psikologis terhadap bias investasi (overconfidence, disposition effect dan herding) di Tehran Stock. Sebanyak 215 orang terlibat dalam penelitian ini, Faktor demografi meliputi jenis kelamin, usia, latar belakang pendidikan, dan area tempat tinggal sedangkan karakter psikologis menggunakan big five personality. Hasilnya menunjukkan bahwa extraversion dan openness to experience mempunyai hubungan yang positif signifikan terhadap overconfidence. Neuroticism mempunyai hubungan yang positif dengan disposition effect dan herding. Conscientiousness mempunyai hubungan yang positif dengan disposition effect dan overconfidence. Tingkat pendidikan mempunyai hubungan langsung terhadap overconfidence. Semakin tinggi pendidikan akan meningkatkan level confidence seseorang. Usia mempengaruhi perilaku investasi mereka. Semakin tua usia investor semakin kecil risiko yang akan mereka ambil.

\section{Hubungan Faktor Demografi dengan Overconfidence}

Faktor demografi meliputi jenis kelamin, usia, pendidikan, pengalaman, dan lama berinvestasi. Eckel dan Grossman (2008) menyatakan bahwa wanita lebih sensitif terhadap risiko daripada pria, hal ini tercermin dalam semua aspek pengambilan keputusan mereka, termasuk pilihan profesi yang akan berpengaruh pada penghasilan, keputusan investasi dan produk yang akan 
dibeli. Menurut Barber dan Odean (2001), laki-laki dalam konteks pengambilan keputusan lebih berani mengambil risiko daripada perempuan. Perempuan digambarkan sebagai pribadi yang tidak terlalu mandiri, sangat emosional, sangat tidak logis, sulit membuat keputusan, kurang peraya diri dan sangat membutuhkan rasa aman. Sebaliknya laki-laki merupakan pribadi yang mandiri, tidak terlalu emosinal, sangat logis, mudah membuat keputusan, sangat percaya diri dan tidak terlalu membutuhkan rasa aman (Setiawati,, 2009). Karena sifatnya ini, laki-laki merasa percaya diri terhadap keputusan investasinya lain halnya dengan perempuan yang selalu punya sikap kehati-hatian menyebabkan perempuan kurang percaya diri dalam membuat keputusan. Lin (2011) juga menemukan hubungan negatif antara gender dan overconfidence yang berarti laki-laki lebih overconfidence daripada perempuan.

$\mathrm{H} 1$ : Terdapat hubungan negatif antara jenis kelamin dengan overconfidence.

Investor dengan usia muda dalam membuat keputusan investasi sangat mempertimbangkan variabel-variabel terkait keputusan investastinya karena pada usia ini masih belum banyak memiliki pengalaman. Investor yang usianya matang tidak banyak mempertimbangkan variabelvariabel investasi dalam kegiatan investasinya karena pada usia ini pengalaman telah banyak didapat sehingga dalam mengambil keputusan investasi lebih pada pengalamannya (Christanti dan Mahastanti, 2011). Hal ini bisa memberi gambaran bahwa semakin matang usia maka investor semakin overconfidence. Hal ini didukung oleh penelitian yang dilakukan Lin (2011) yang menemukan adanya hubungan positif antara usia dengan overconfidence.

$\mathrm{H} 2$ : Terdapat hubungan positif antara usia dengan overconfidence.

Bhandari dan Deaves (2006) dalam penelitiannya menemukan semakin tinggi tingkat pendidikan seseorang maka mereka akan cenderung overconfidence dalam pengambilan keputusan. Tingkat pendidikan yang lebih tinggi membuat seorang investor merasa lebih kompeten dalam hampir semua bidang termasuk keuangan (Heath dan Tversky, 1991). Oleh karena itu, kebanyakan investor yang berpendidikan melakukan investasi berdasarkan pengetahuan, kemampuan dan kepercayaan diri mereka sendiri (Jamshidinavid et al, 2012). Hal ini berarti semakin tinggi tingkat pendidikan akan meningkatkan level kepercayaan diri. Ini membuktikan bahwa investor yang berpendidikan semakin tinggi rentan overconfidence.

H3 : Terdapat hubungan positif antara pendidikan dengan overconfidence.

Christanti dan Mahastanti (2011) lamanya investasi mempengaruhi keputusan investasi investor, bagi investor yang masih baru dalam berinvestasi sangat mempertimbangkan semua faktor yang berhubungan dengan keputusan investastinya. Sedangkan semakin lama seorang investor melakukan investasi maka semakin berkurang atau semakin sedikit faktor yang dipertimbangkan sebab semakin lama semakin banyak pengalaman sehingga keputusan investasi lebih banyak berdasarkan pengalaman. Overconfidence seseorang meningkat ketika mendapatkan lebih banyak pengalaman investasi (Alrabadi et al, 2011). Studi yang dilakukan oleh Glaser et al. (2005) juga menemukan bahwa professional traders biasanya memiliki tingkat overconfidence yang lebih tinggi dibandingkan dengan mahasiswa. Hal ini membuktikan bahwa ada hubungan antara lama investasi dengan overconfidence. Zaidi dan Tauni (2012) dan Alrabadi et al (2011) hasil penelitian mereka menemukan adanya hubungan positif antara pengalaman investasi dengan overconfidence.

H4 : Terdapat hubungan positif lama investasi dengan overconfidence.

\section{Hubungan Karakteristik Personal dengan Overconvidence}

Kepribadian dalam penelitian ini dilihat berdasarkan TheBig five Personality yang dikembangkan oleh McCrae. Karakteristik kelima trait dalam pendekatan Big Five adalah extraversion, agreeableness, conscientiousness, neuroticism serta openness (Costa \& McCrae, 1996). 
Extraversion dicirikan dengan kecenderungan yang positif seperti memiliki antusiasme tinggi, mudah bergaul, energik, tertarik dengan banyak hal, mempunyai emosi yang positif, ambisius, workaholic serta ramah terhadap orang lain. Hal ini dapat diartikan bahwa orang yang mempunyai skor extraversion yang tinggi akan mempunyai kecenderungan kepercayaan diri yang tinggi karena mereka mampu untuk bergaul, selalu ambisius dan mempunyai sifat antusiasme yang tinggi. Hal ini dapat dibuktikan dari hasil penelitian Bhasir et,al (2013), Schaefer et,al (2004), dan Jamshidinavid et,al (2012) yang menyatakan bahwa extraversion memiliki hubungan positif dengan overconvidence.

H5 : Terdapat hubungan positif antara extraversion dengan overconfidence.

Individu dengan skor agreebleness yang tinggi memiliki kecenderungan untuk memilki kepercayaan diri yang penuh, dermawan, suka mengalah, penerima dan baik hati. Faktor ini juga disebut dengan social adaptability atau likability, yaitu mencirikan seseorang yang ramah, memiliki kepribadian yang selalu mengalah dan menghindari konflik. Sifat daripada agreebleness yang mempunyai kepercayaan yang penuh, patuh, dan penerima ini dapat diartikan sebagai orang yang mudah percaya terhadap sesuatu. Investor yang mempunyai sifat agreebleness yang tinggi cenderung lebih mudah percaya pada informasi pasar yang ada sehingga akan menimbulkan kepercayaan diri yang berlebih (Zaidi dan Tauni, 2012). Lin (2011) dan Bashir et al (2013) hasil penelitiannya menyebutkan bahwa adanya hubungan positif antara agreeableness dengan overconfidence.

H6 : Terdapat hubungan positif antara agreeableness dengan overconfidence.

Conscientiousness digambarkan dengan individu yang patuh, terkonrol, teratur, ambisius, berfokus pada pencapaian, dan disiplin diri. Faktor ini dapat juga disebut dengan dependability, impulse control dan will to achieve. Secara umum individu yang memiliki skor tinggi pada faktor ini akan menjadi pekerja keras, cermat, tepat waktu, dan tekun. Individu yang seperti ini memiliki kecenderungan sifat yang percaya diri akan dirinya sendiri untuk mencapai tujuan. Schaefer et al, ( 2006) menyebutkan bahwa investor dengan trait conscientiousness yang tinggi cenderung overconfidence. Investor dengan trait ini percaya pada kinerja mereka sendiri dalam berinvestasi dan merasa lebih baik daripada investor lainnya (Lin, 2011). Oleh karena itu, investor dengan trait conscientiousness yang tingi sangat rentan untuk bersikap overconfidence. Hal ini didukung oleh penelitian Zaidi dan Tauni (2012) serta Lin (2011) yang menemukan ada hubungan positif antara conscientiousness dengan overconfidence.

H7: Terdapat hubungan positif antara conscientiousness dengan overconfidence.

Neuroticism dicirikan dengan kecenderungan mengalami kecemasan, temperamental, mengasihani diri sendiri, sadar diri, emosional dan rentan terhadap gangguan stress. Venter dan Michayluk (2008) mengatakan investor akan kurang percaya diri ketika mereka mempunyai perilaku cemas. Investor dengan traitneuroticism akan merasa cemas, emosi tidak stabil dan gugup. Investor dengan traitneuroticism juga akan mudah depresi sehingga kepercayaan diri kemudian menurun (Lin, 2011 dan Stone et al., 2011 ). Hal ini didukung oleh penelitian Zaidi dan Tauni (2012) serta Bashir et al. (2013) yang menemukan hubungan negatif antara neuroticism terhadap overconfidence.

H8 : Terdapat hubungan negatif antara neuroticism dengan overconfidence.

Openness to experience memiliki ciri mudah bertoleransi, memiliki kapasitas dalam menyerap informasi, fokus dan mampu waspada pada berbagai perasaan, pemikiran dan impulsivitas. Individu yang mempunyai skor tinggi pada sifat ini akan menjadi individu yang terus-menerus mencari perbedaan dan pengalaman yang bervariasi. Sifat dari openness to experience yang penasaran dan suka mencari informasi baru membuat investor dengan trait ini 
seringkali melakukan transaksi menjual dan membeli saham yang disebabkan oleh kepercayaan diri yang tinggi (Odean.T, 1999). Dari sini terlihat bahwa openness to experience rentan untuk bersikap overconfidence dalam investasi. Hal ini didukung oleh hasil penelitian Lin (2011) serta Zaidi dan Tauni (2012) yang menemukan adanya hubungan positif antara openness to experience dengan overconfidence.

H9 : Terdapat hubungan positif antara openness to experience dengan overconfidence.

\section{Metode Penelitian}

Populasi yang digunakan dalam penelitian ini adalah investor saham berdomisili di Yogyakarta yang sedang melakukan perdagangan saham di Bursa Efek Indonesia (BEI). Pengambilan sampel dilakukan dengan menggunakan random sampling. Sampel yang digunakan dalam penelitian ini adalah investor saham di Bursa Efek Indonesia (BEI) dengan minimal waktu transaksi yang pernah dilakukan adalah satu tahun, berusia minimal 18 tahun dan mempunyai kecenderungan overconfidence.

Penelitian ini yang berisi 44 soal pernyataan personality traits dan 5 soal pernyataan overconfidence. Sebelum kuesioner disebar, kuesioner diuji validitas dan realibiltasnya menggunakan pearson correlation dan cronbach's alpha. Dari hasil uji valid ditemukan 9 butir soal personality traits dan 1 butir soal overconfidence dinyatakan tidak valid $(r<0,30)$, sehingga dilakukan pengujian ulang kembali dengan sebelumnya dilakukan perubahan kata menjadi lebih sederhana dan penambahan satu soal overconfidence. Hasil pengujian kedua menyatakan 2 butir soal personality traits yaitu no. 35 dan 38 dan satu soal overconfidence yaitu no. 3 dinyatakan tidak valid. Kemudian diputuskan untuk mengeliminasi butir soal yang tidak valid karena soal yang lain sudah dapat mewakili dalam memberikan gambaran mengenai responden. Dari hasil uji reliabilitas menyatakan semua soal telah reliable yakni nilai cronbach's alphas 0,60. Oleh karena itu, dalam penelitian ini dari 44 soal pernyataan personality traits hanya menggunakan 42 pernyataan dan menggunakan 5 soal pernyataan overconfidence.

Metode analisis data yang digunakan dalam penelitian ini adalah chi square dan pearson correlation. Uji chi square digunakan unrk menguji hubungan antara jenis kelamin, usia, pendidikan dan lama investasi terhadap overconfidence. Uji pearson correlation digunakan untuk menguji hubungan antara extraversion, agreeableness, neuroticisim, conscientiousness dan openness to experience terhadap overconfidence. Kriteria pengujian chi square dan pearson correlation dengan melihat taraf signifikansi $(\alpha)$, yaitu jika p-value $<0.05$ maka Ho ditolak, dan jika p-value> 0.05 maka Ho diterima.

\section{Hasil Analisis dan Pembahasan}

Sebanyak 100 kuesioner kemudian disebar diberbagai kantor-kantor sekuritas dan Universitas yang ada di Yogyakarta. Dari hasil penyebaran kuesioner, sebanyak 87 kuesioner digunakan sedangkan 13 lainnya didiskualifikasi karena jawaban yang tidak lengkap. Karakteristik responden dapat dilihat pada Tabel 1.

Penelitian ini mengkhususkan pada subjek yang berperilaku overconfidence sehingga data yang akan diolah kemudian adalah responden yang hanya memiliki tingkat kepercayaan diri yang tinggi (overconfidence) yang dalam penelitian ini berjumlah 71 responden. Proporsi overconfidence responden di Yogyakarta disajikan dalam Gambar 3. 
Tabel 1. Karakteristik Responden

\begin{tabular}{clc}
\hline \multicolumn{2}{c}{ Karakteristik } & Presentase \\
\hline \multirow{2}{*}{ Jenis kelamin } & Laki-laki & $66 \%$ \\
& Perempuan & $34 \%$ \\
\hline \multirow{6}{*}{ Usia } & $18-25$ tahun & $61,9 \%$ \\
& $26-33$ tahun & $19,6 \%$ \\
& $34-41$ tahun & $11,3 \%$ \\
& $>41$ tahun & $7,2 \%$ \\
\hline \multirow{5}{*}{ Pendidikan } & SMA & $26,8 \%$ \\
& Diploma/D3 & $11,3 \%$ \\
& S1 & $60,8 \%$ \\
& S2 & $1 \%$ \\
& S3 & $0,00 \%$ \\
\hline \multirow{3}{*}{ Lama investasi } & $1-3$ tahun & $78,4 \%$ \\
& $4-6$ tahun & $13,4 \%$ \\
& $>6$ tahun & $8,2 \%$ \\
\hline
\end{tabular}

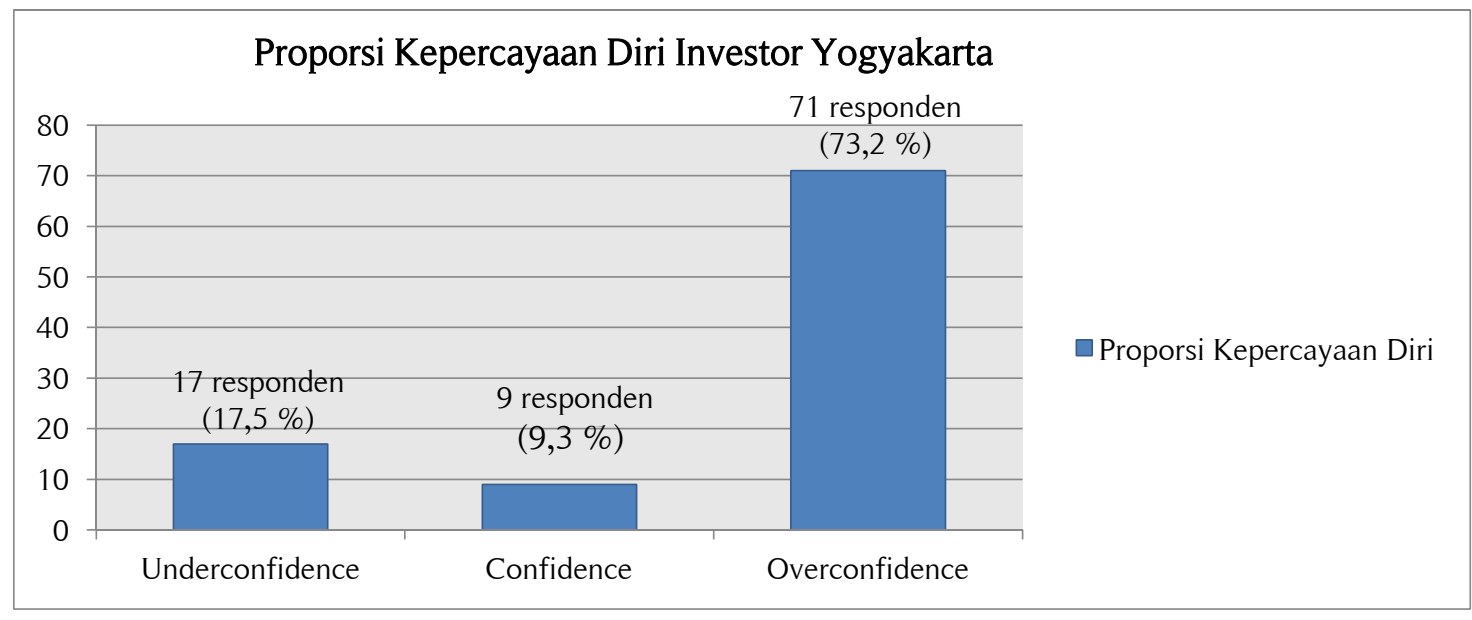

Gambar 2. Proporsi kepercayaan diri investor Yogyakarta

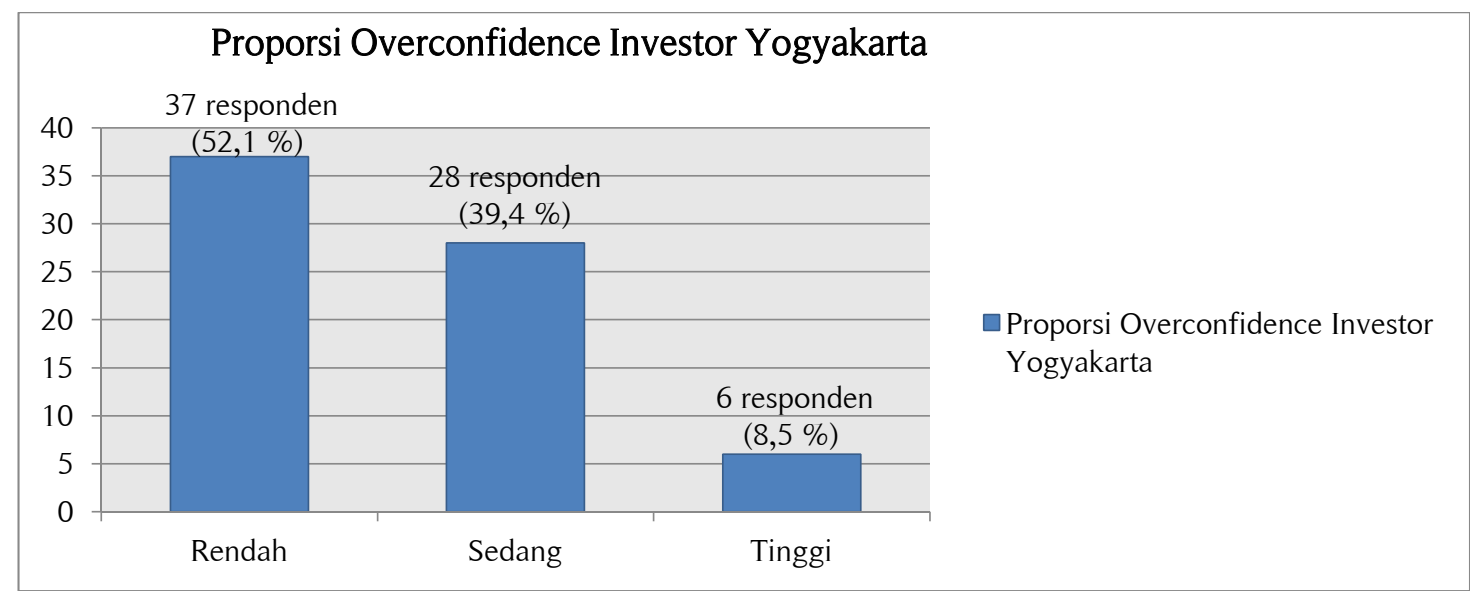

Gambar 3. Tingkat Overconfidence Investor Yogyakarta

Hasil Klasifikasi Silang Faktor Demografi dengan Overconfidence 


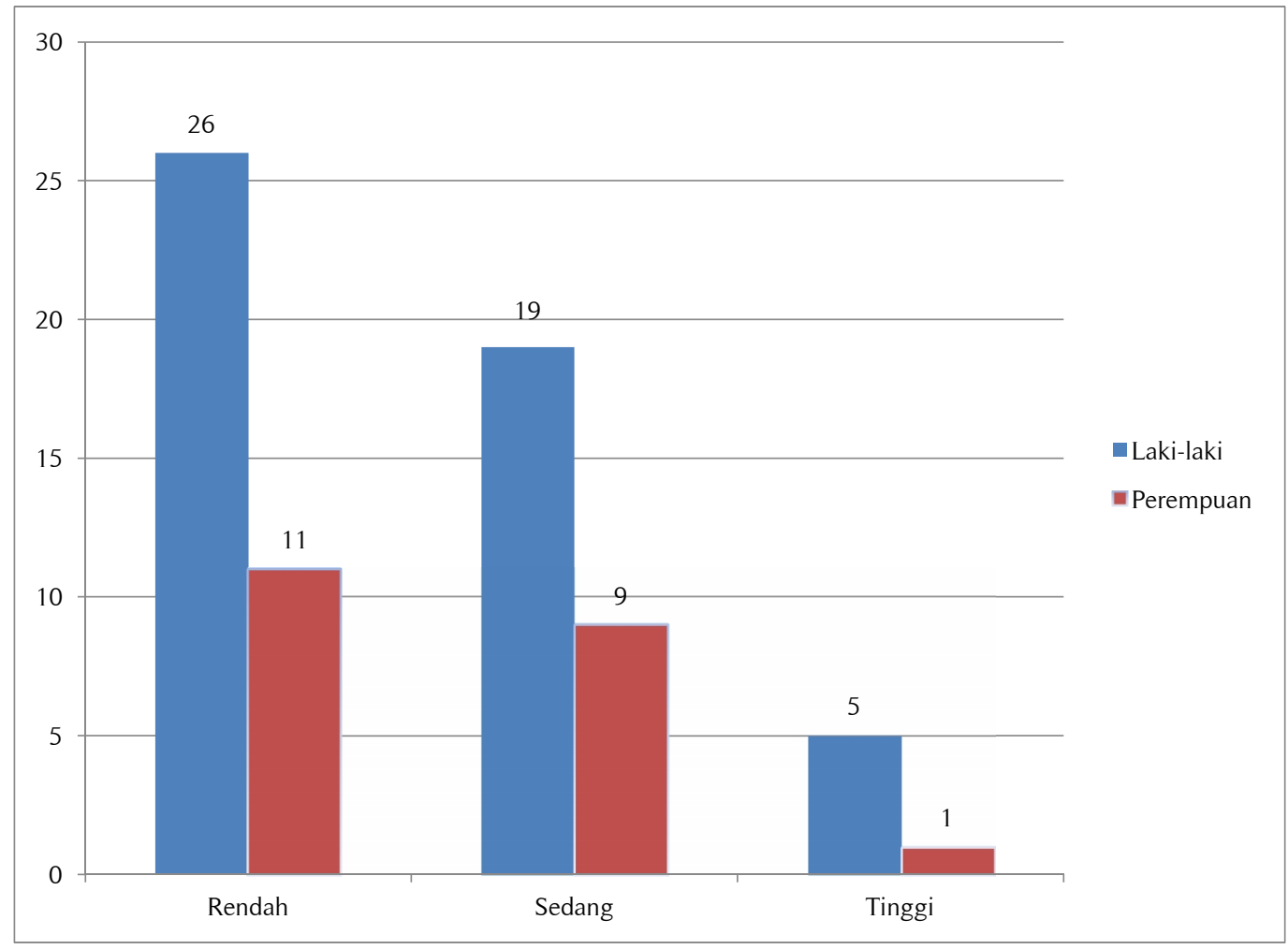

Gambar 4. Klasifikasi silang jenis kelamin dengan overconfidence

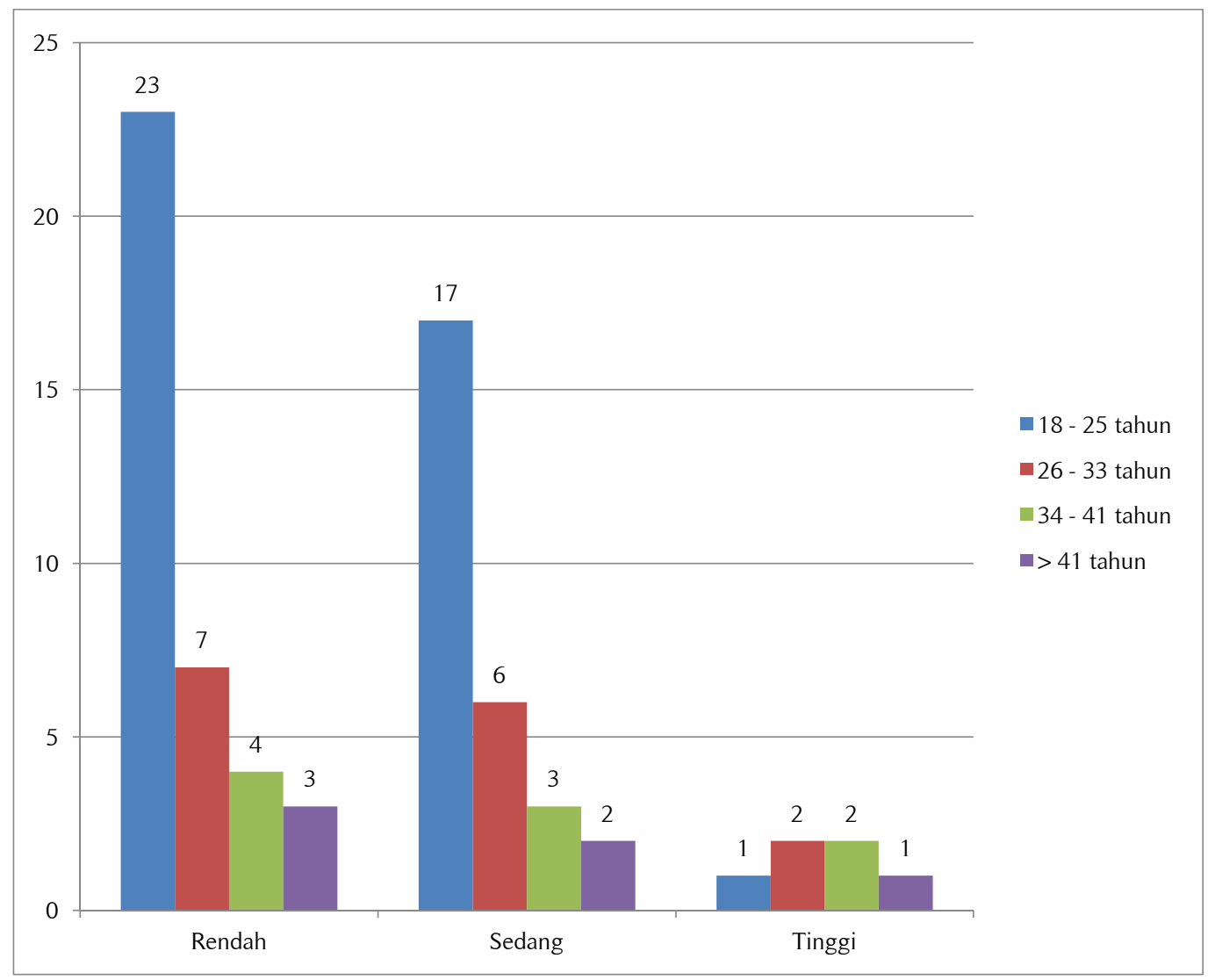

Gambar 5. Klasifikasi silang usia dengan overconfidence 


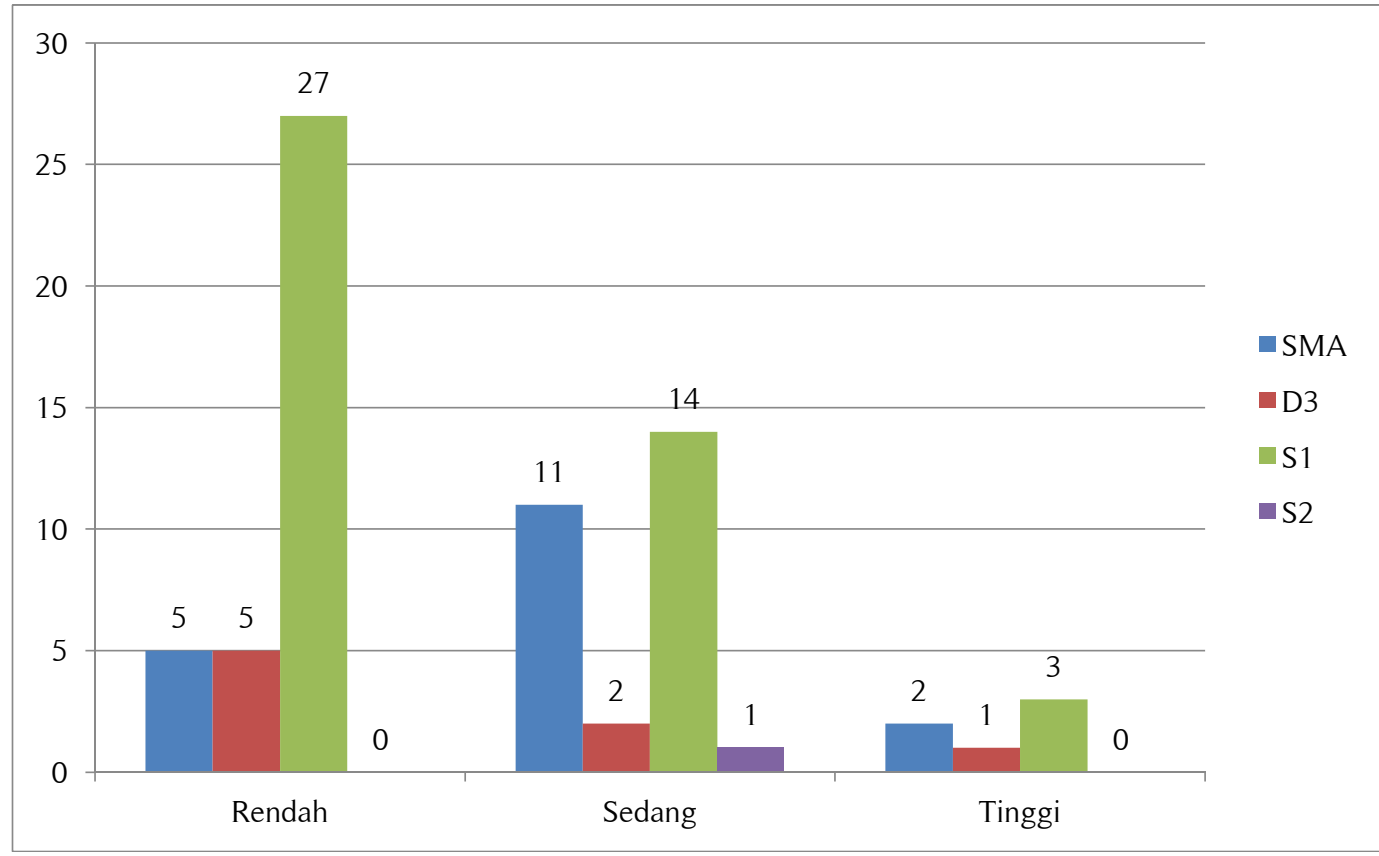

Gambar 6. Klasifikasi silang pendidikan dengan overconfidence

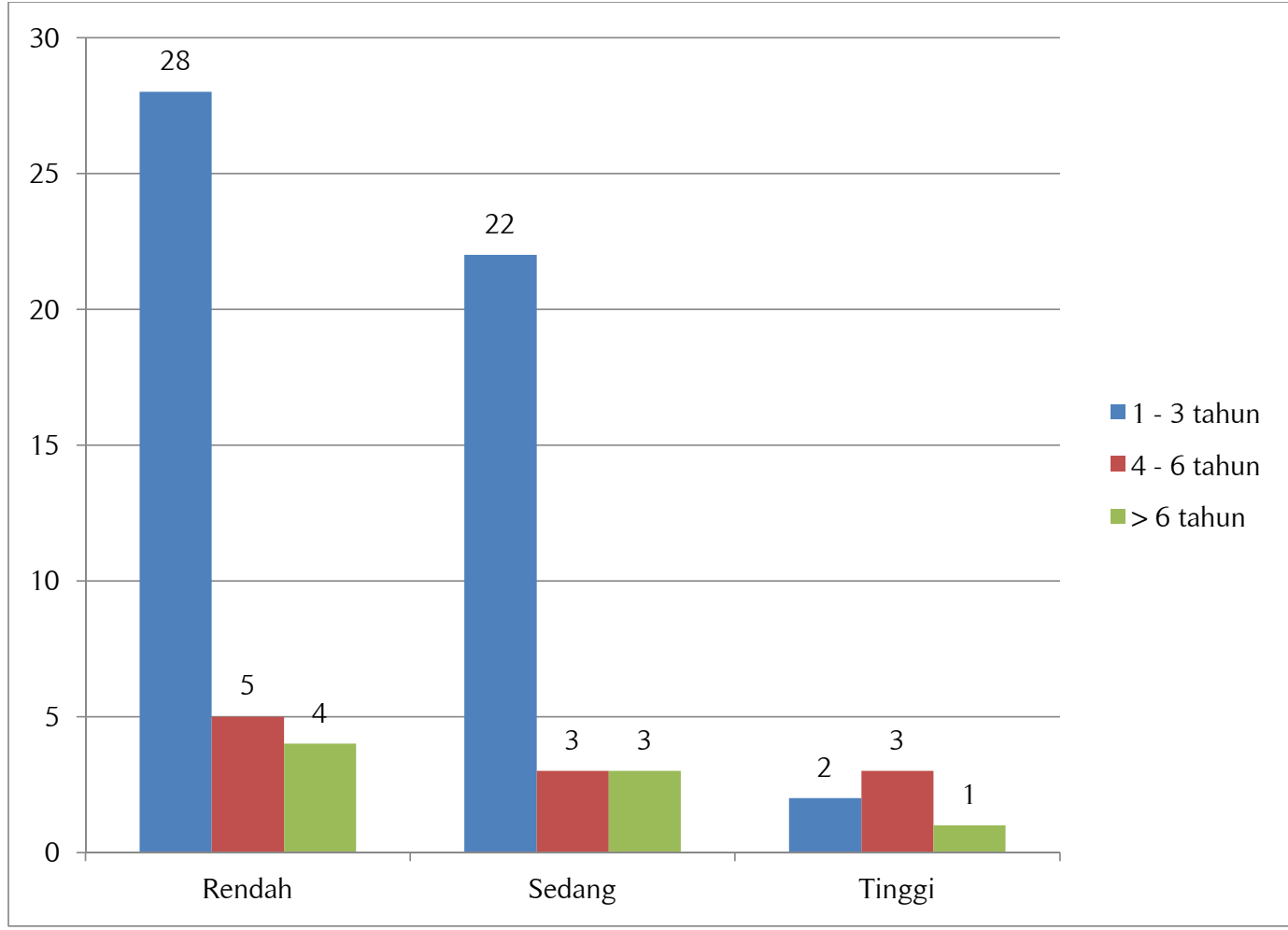

Gambar 7. Klasifikasi silang pengalaman investasi dengan overconfidence

Dari hasil uji normalitas data terlihat hasil sebagai berikut: nilai koefisien kolmogorovsmirnov variabel extraversion sebesar 0.463 , variabel agreeableness sebesar 0.225 , variabel Conscientiousness sebesar 0.235 , variabel neuroticism sebesar 0.606 , variabel openness to experience sebesar 0.491 dan variabel overconfidence sebesar 0.054 . Syarat kenormalan data pada kolmogorov-smirnov adalah nilai koefisiennya lebih besar (>) dari 0.05. Berdasarkan dari 
data yang diolah dapat kita simpulkan bahwa semua variabel telah berdistribusi normal sehingga data selanjutnya dapat diolah dengan menggunakan uji korelasi pearson.

\section{Hasil Uji Hubungan Faktor Demografi dan Overconvidence}

Hasil uji hubungan faktor demografi dan overconfidence dapat dilihat pada tabel 2.

Tabel 2. Hubungan Faktor Demografi Dan Overconvidence

\begin{tabular}{llcccc}
\hline \multirow{2}{*}{ Fverconfidence } & Faktor Demografi & $\begin{array}{c}\text { Chi Square } \\
\text { Value }\end{array}$ & Df & $\begin{array}{c}\text { Tingkat } \\
\text { Signifikansi }\end{array}$ & Keterangan \\
\cline { 2 - 5 } & Jenis Kelamin & 0.569 & 2 & 0.752 & Ho diterima \\
& Usia & 5.178 & 6 & 0.521 & Ho diterima \\
& Pendidikan & 8.129 & 6 & 0.229 & Ho diterima \\
& Lama investasi & 6.731 & 4 & 0.151 & Ho diterima \\
\hline
\end{tabular}

a) Hubungan antara jenis kelamin dengan overconfidence

Pada penelitian ini diperoleh hasil yang menyatakan tidak terdapat hubungan antara jenis kelamin dengan overconfidence. Hal ini kemungkinan terjadi karena saat ini perempuan telah memiliki pengetahuan dan pendidikan yang sejajar dengan laki-laki sehingga membuat kepercayaan diri kaum perempuan meningkat. Pada zaman sekarang perempuan memiliki rasa kemandirian dan tanggung jawab yang tinggi, terbukti dari Tabel 2 bahwa dari 87 responden yang berivestasi di saham ada $34 \%$ yang berjenis kelamin perempuan. Investasi saham merupakan investasi yang tinggi resikonya. Perempuan yang memilih investasi saham kemungkinan besar telah memiliki kepercayaan diri yang tinggi. Penelitian ini sejalan dengan penelitian yang dilakukan oleh Zaidi dan Tauni (2012) dan Alrabadi et al. (2011) yang menyatakan tidak terdapat hubungan antara jenis kelamin dengan overconfidence. Namun, hasil dari penelitian ini tidak sejalan dengan penelitian yang dilakukan oleh Bhandari dan Deaves (2006) yang menemukan adanya hubungan jenis kelamin dengan overonfidence.

b) Hubungan antara usia dengan overconfidence

Pada penelitian ini diperoleh hasil yang menyatakan tidak adanya hubungan antara usia dengan overconfidence. Saat ini semakin muda usia, semangat untuk mengetahui hal-hal yang baru sangat tinggi sehingga membuat individu muda menjadi overconfidence. Dari Tabel 2 diatas terlihat bahwa 61,9\% yang berinvestasi di saham adalah usia muda, ini mengindikasikan bahwa orang muda sekarang overconfidence. Investor tua yang telah hidup lebih lama juga mempunyai kepercayaan diri yang tinggi karena merasa telah mempunyai pengalaman hidup yang lebih banyak. Penelitian ini sejalan dengan Bashir et al. (2013) dan Alrabadi et al (2011) yang menyatakan tidak adanya hubungan usia dengan overconfidence. Namun, penemuan ini tidak sejalan dengan hasil yang didapat oleh Lin (2011) yang menemukan bahwa terdapat hubungan antara usia dengan overconfidence, investor tua akan lebih overconfidence dibanding investor muda.

c) Hubungan antara pendidikan dengan overconfidence

Pada penelitian ini diperoleh hasil yang menyatakan tidak ada hubungan antara pendidikan dengan overconfidence. Kemungkinan hal ini terjadi karena semakin berkembangnya dunia teknologi dan social media yang memungkinkan orang dari latar belakang pendidikan manapun dapat belajar secara otodidak dengan mengikuti forum-forum diskusi terbuka yang membahas mengenai investasi saham dipasar modal atau dengan media lainnya. Dengan banyak mengikuti forum-forum diskusi investor mendapatkan banyak informasi hal ini yang rentan menyebabkan overconfidence. Terbukti dari Tabel 2 diatas ada 26,8\% investor saham berpendidikan SMA sedangkan yang berpendidikan S2 hanya 1\%. Hasil penelitian ini sejalan dengan penelitian Alrabadi et al. (2011) dan Bashir et al (2013) yang menyatakan tidak terdapat hubungan antara pendidikan dengan overconfidence. Hasil ini tidak sejalan dengan 
penelitian yang dilakukan oleh Bhandari dan Deaves (2006) yang menemukan adanya hubungan antara tingkat pendidikan dengan overconfidence.

d) Hubungan antara lama investasi dengan overconfidence

Pada penelitian ini diperoleh hasil yang menyatakan tidak ada hubungan antara lama investasi dengan overconfidence. Kemungkinan hal ini terjadi karena investor pemula yang pada saat mau melakukan investasi mendapat saran dari orang-orang yang dianggapnya telah ahli dalam berinvastasi dan mereka mengikuti saran tersebut. Investor pemula menganggap saran-saran dari investor yang telah ahli lebih tepat dalam memprediksi investasi yang baik. Oleh karena itu, kepercayaan diri investor pemula sangat rentan menjadi overconfidence. Kemudian investor yang memiliki pengalaman yang banyak dalam mengambil keputusan lebih mengikuti pengalaman berdasarkan masa lalunya terlebih ketika pengalamannya tersebut merupakan pengalaman yang menggembirakan yaitu mendapatkan keuntungan yang banyak. Hal ini yang mungkin menyebabkan tidak terdapatnya hubungan antara lama investasi dengan overconfidence. Hasil penelitian ini sejalan dengan hasil penelitian Sutomo (2013) yang menemukan tidak adanya hubungan antara lama investasi dengan overconfidence tetapi tidak sejalan dengan hasil penelitian Zaidi dan Tauni (2012) dan Alrabadi et al. (2011) yang menemukan terdapat hubungan antara lama investasi dengan overconfidence.

\section{Hasil Uji Hubungan Personality Traits dan Overconfidence}

Hasil uji hubungan personality traits dan overconfidence dapat dilihat pada tabel 2 di bawah ini.

Tabel 2. Hubungan Personality Traits dan Overconfidence

\begin{tabular}{llccc}
\hline \multicolumn{1}{c}{ Personality traits } & $\begin{array}{c}\text { Koefisien } \\
\text { Korelasi }(\mathrm{r})\end{array}$ & $\begin{array}{c}\text { Tingkat } \\
\text { Signifikansi }\end{array}$ & Keterangan \\
\cline { 2 - 5 } Overconfidence & Extraversion & 0.050 & 0.679 & Ho diterima \\
& Agreeableness & 0.020 & 0.870 & Ho diterima \\
& Conscientiousness & $0.310^{* *}$ & 0.008 & Ho ditolak \\
& Neuroticism & -0.191 & 0.110 & Ho diterima \\
& $\begin{array}{l}\text { Openness to } \\
\text { experience }\end{array}$ & 0.101 & 0.404 & Ho diterima \\
\hline
\end{tabular}

* Significant Relationship Exists

Sumber: data primer yang diolah, 2016.

\section{Hubungan Personality Traits dan Overconfidence}

a) Hubungan antara extraversion terhadap overconfidence

Hasil penelitian menunjukkan extraversion tidak memiliki hubungan dengan overconfidence. Extraversion dicirikan dengan kecenderungan yang positif seperti memiliki antusiasme tinggi, mudah bergaul, energik, tertarik dengan banyak hal, mempunyai emosi yang positif, ambisius, workaholic serta ramah terhadap orang lain. Hal ini dapat diartikan bahwa orang yang mempunyai skor extraversion yang tinggi akan mempunyai kecenderungan kepercayaan diri yang tinggi karena mereka mampu untuk bergaul, selalu ambisius dan mempunyai sifat antusiasme yang tinggi. Namun hasil penelitian ini menunjukkan bahwa psikologis investor mudah terpengaruh oleh faktor eksternal seperti kondisi pasar saham, sehingga pada saat saham investor mengalami kerugian yang cukup besar yang diakibatkan oleh kondisi pasar yang melemah, kepercayaan diri investor kemudian ikut menurun. Hasil penelitian ini sejalan dengan penelitian yang dilakukan oleh Bashir et al. (2013) yang tidak menemukan adanya hubungan antara extraversion dengan overconfidence. Namun, hasil ini tidak sejalan dengan penelitian yang dilakukan oleh Jamshidinavid et al (2011) dan Lin (2011) yang menemukan adanya hubungan positif antara extraversion dengan overconfidence. 
b) Hubungan antara agreeableness terhadap overconfidence

Sejalan dengan extraversion, faktor agreeableness pada penelitian ini juga tidak terdapat hubungan dengan overconfidence. Individu dengan skor agreebleness yang tinggi memiliki kecenderungan untuk memilki kepercayaan diri yang penuh, dermawan, suka mengalah, penerima dan baik hati. Faktor ini juga disebut dengan social adaptability atau likability, yaitu mencirikan seseorang yang ramah, memiliki kepribadian yang selalu mengalah dan menghindari konflik. Sifat daripada agreebleness yang mempunyai kepercayaan yang penuh, patuh, dan penerima ini dapat diartikan sebagai orang yang mudah percaya terhadap sesuatu. Investor yang mempunyai sifat agreebleness yang tinggi cenderung lebih mudah percaya pada informasi pasar yang ada sehingga akan menimbulkan kepercayaan diri yang berlebih (Zaidi dan Tauni, 2012). Namun hasil penelitian menunjukkan bahwa investor saham di Yogyakarta dalam berinvestasi mudah terpengaruh oleh faktor eksternal. Faktor eksternal tersebut bisa berupa informasi pasar, kondisi pasar, keadaan politik dan faktor lainnya yang secara signifikan dapat mempengaruhi kondisi psikologis investor (Masomi \& Ghayekhloo, 2011). Hal ini juga didukung oleh sifat dasar dari agreeableness yang patuh dan penerima sehingga mereka akan mudah terpengaruh faktor dari luar sehingga kepercayaan diri mereka menurun. Hasil ini sejalan dengan penelitian yang dilakukan oleh Lin (2011) dan Jamshidinavid et al. (2011) yang tidak menemukan adanya hubungan antara agreeableness dengan overconfidence. Namun hasil ini tidak sejalan dengan penelitian yang dilakukan oleh Zaidi dan Tauni (2012).

c) Hubungan antara conscientiousness terhadap overconfidence

Dari hasil yang diperoleh menunjukkan bahwa ada hubungan antara conscientiousness dengan overconfidence yang artinya orang-orang yang memiliki sifat pekerja keras, cermat, tepat waktu dan tekun memiliki kecenderungan overconfidence. Investor dengan conscientiousnes terbukti percaya pada kinerja mereka sendiri dalam berinvestasi dan merasa lebih baik daripada investor lainnya. Investor dengan conscientiousness bersikap demikian karena mereka merasa mampu memprediksi kinerja pasar dan memiliki ketepatan dalam memprediksi harga sehingga mereka menjadi overconfidence. Hasil penelitian ini sejalan dengan Zaidi dan Tauni (2012) dan Lin (2011) yang menemukan hubungan antara conscientiousness dengan overconfidence. Namun, hasil ini tidak sejalan dengan penelitian Bashir et al (2013).

d) Hubungan antara neuroticism terhadap overconfidence

Hasil pengujian menunjukkan bahwa tidak terdapat hubungan antara neuroticism dengan overconfidence. Neuroticism dicirikan dengan kecenderungan mengalami kecemasan, temperamental, mengasihani diri sendiri, sadar diri, emosional dan rentan terhadap gangguan stress. Venter dan Michayluk (2008) mengatakan investor akan kurang percaya diri ketika mereka mempunyai perilaku cemas. Investor dengan traitneuroticism akan merasa cemas, emosi tidak stabil dan gugup. Investor dengan traitneuroticism juga akan mudah depresi sehingga kepercayaan diri kemudian menurun (Lin, 2011) yang mana depresi juga berhubungan dengan underconfidence (Stone et al., 2011). Hasil pengujian menunjukkan bahwa investor dengan trait neuroticism kekhawatiran yang ada didalam diri mereka akan mudah terpengaruh oleh faktor-faktor eksternal seperti informasi pasar, kondisi pasar, faktor ekonomi, faktor politik dan sebagainya yang kemudian dapat mempengaruhi keadaaan psikologis mereka (Masomi \& Ghayekhloo, 2011). Dari hasil ini investor dengan neuroticism yang awalnya cemas, khawatir, depresi akan menjadi lebih percaya diri setelah menerima berita positif dari pasar. Hal ini sejalan dengan penelitian Jamshividinaid et al. (2011), dan Lin (2011) yang menemukan tidak adanya hubungan antara neuroticism dengan overconfidence. Namun hasil ini tidak sejalan dengan Zaidi dan Tauni (2012).

e) Hubungan antara openness to experience terhadap overconfidence 
Hasil pengujian menunjukkan bahwa tidak ada hubungan antara openness to experience dengan overconfidence. Openness to experience memiliki ciri mudah bertoleransi, memiliki kapasitas dalam menyerap informasi, fokus dan mampu waspada pada berbagai perasaan, pemikiran dan impulsivitas. Individu yang mempunyai skor tinggi pada sifat ini akan menjadi individu yang terus-menerus mencari perbedaan dan pengalaman yang bervariasi. Sifat dari openness to experience yang penasaran dan suka mencari informasi baru membuat investor dengan trait ini seringkali melakukan transaksi menjual dan membeli saham yang disebabkan oleh kepercayaan diri yang tinggi (Barber dan Odean, 1999). Dari sini terlihat bahwa openness to experience rentan untuk bersikap overconfidence dalam investasi. Tetapi hasil pengujian menunjukkan bahwa investor dalam bertransaksi lebih dipengaruhi oleh kondisi eksternal hal ini mempengaruhi perubahan psikologis investor secara signifikan (Masomi \& Ghayekhloo, 2011). Contoh pada saat faktor ekonomi investor memburuk, meskipun pada dasarnya investor dengan traitopenness to experience sering menjual dan membeli saham (Barber dan Odean, 1999), namun ketika keadaan ekonomi investor memburuk, hal ini membuat investor lebih teliti dalam melakukan keputusan investasi dan dapat menimbulkan kecemasan pada diri investor sendiri. Kecemasan ini akan menyebabkan kepercayaan diri investor menurun (Venter dan Michayluk, 2008). Hasil ini sejalan dengan penelitian yang dilakukan Schaefer et al. (2004) yang tidak menemukan adanya hubungan antara openness to experience dengan overconfidence. Namun hasil ini tidak sejalan dengan penelitian yang dilakukan oleh Zaidi dan Tauni (2012) dan Lin (2011).

\section{Kesimpulan dan Saran}

Berdasarkan hasil penelitian maka dapat disimpulkan bahwa overconvidence investor saham di Yoyakarta tidak dipengaruhi oleh faktor demografi yang berupa usia, jenis kelamin, pendidikan dan lama investasi. Hasil ini ditunjukkan dengan besarnya nilai p-value chi square semua faktor demografi lebih besar dari 0.05. Hasil penelitian ini juga menemukan bahwa overconvidence investor saham di Yogyakarta tidak berhubungan dengan faktor personality traits (extraversion, agreeableness, conscientiousness, neuroticism dan openness to experience). ditemukan satu personality traits yang berhubungan dengan overconfidence yaitu conscientiousness.

Dari hasil penelitian, disarankan bagi peneliti selanjutnya: 1) Diharapkan untuk menambahkan faktor demografi lain seperti etnis, status perkawinan, jenis pekerjaan, jumlah tanggungan, dan pengeluaran per bulan. 2). Penelitian ini hanya berfokus pada bias overconvidence masih banyak bias investasi yang lain yang mempengaruhi investor dalam mengambil keputusan berinvestasi. Bias- bias tersebut diantaranya self control, reliance on expert, bride, regret dan status quo, oleh karena itu disarankan untuk penelitian berikutnya menambah faktor internal ini.

\section{Daftar Pustaka}

Alrabadi, D. W., Al-Gharaibeh M. A., \& Zurigat Z., M. (2011). What Makes Investor Overconfident? Evidence from Amman Stock Exchange. European Journal of Economics, Finance and Administrative Sciences.

Barber, M. B., \& Odean, T. (2001). Boys Will Be Boys: Gender, Overconfidence, and Common Stock Investment. Quarterly Journal of Economics, February.

Barberis, N \& R. H. Thaler.( 2003). A. Survey of Behavioral Finance; in G. M Constantiniedes, M. Harris \& R. Stulz: Handbook of the Economic of Finance; Elsevier.

Bashir, T; Safia, F; Irum, S; Waqas, A; \& Ghullam, J. (2013). Impact of Demographics and Personality traits on Confidence level: Determinants of overconfidence (Evidence from 
Employees and Students). IOSR Journal of Business and Management, vol. 10, isuue 1, pp 58-67.

. (2013). Are Behavioral Biases Influenced By Demographic Characteristics and Personality traits? Evidence From Pakistan. European Scientific Journal vol. 9, No. 29.

Bhandari, G. \& Deaves, R. (2006). The Demographics of Overconfidence. The Journal of Behavioral Finance, vol. 7, No. 7, pp. 5-11.

Christansti, N., \& L. A. Mahastanti. (2011). Faktor-faktor yang Dipertimbangkan Investor dalam Melakukan Investasi. Jurnal Manajemen Teori dan Terapan tahun 4, no. 3.

Costa, P.T., Jr. \& McCrae, R. R. (1996). Toward a New Generation of Personality Theories: Theoritical Contexts for the Five Faktor Model. New York: Guilford.

Eckel, C. \& Grossman P. (2008). Men, Women and Risk Aversion: Experimental Evidence. Handbook of Experimental Ecnomics Results, vol. 1.

Fraser, P.(2003). How do US and Japanese investors process information, and how do they form their expectation of the future? Evidence from quantitative survey based data. Journal of Asset Finance Vol 53, 77-90.

Fischhoff, B, P. Slovic, \& Linchtenstein, S. (1977). Knowing with Certainty: The Appropriateness of Extreme Confidence. Journal of Experimental Psychology: Human Perception and Performance vol. 3, no. 4, 552-564.

Gervais, S., \& Odean, T. (2001). Learning to Be Overconfident. The Review of Financial Studies Spring, vol. 14, no. 1, pp. 1-27.

Glaser, M., Langer, T., \& Weber, M. (2005). Overconfidence of Professionals and Lay men: individual Differences Within and Between Tasks?. Working Paper, University of Mannheim.

Heath.C, \& A. Tversky. (1991). Preference and Belief Ambiguity and Competence Choice Under Uncertainty. Journal of Risk and Uncertainty, 4. 5-28.

http://www.harianjogja.com/baca/2016/05/11/pasar-modal-diy-banyak-saham-tidur-investordiminta-lebih-jeli-718251.

Iramani, Rr dan Dhyka, B. (2008). Faktor-faktor Penentu Perilaku Investor dalam Transaksi Saham di Surabaya, Vol, 6 (3), 255-262.

Jain, D \& Mandodt, E. (2012). Impact of Demographic Faktors on Investors in Rajasthan, Journal of Arts, Science \& Commerce, E-ISSN 2229-4686.

Jamshidinavid, B., MojtabaChavoshani, \& Amiri, S. (2012). The Impact of Demographic and Psychological Characteristics on the Investment Prejudices in Tehran Stock. European Journal of Business and Social Sciences, vol. 1, no. 5, pp 41-53.

Linchtenstein,S; \& B. Fischhoff (1977). Do Those who Know More also Know More abaout how Much they Know? The Calibration of Probability Judgments, Organizational Behavior and Human Performannce 20, 157-183.

Lin, H.-W. (2011). Elucidating the Influence of Demographics and Psychological Traits on Investment Biases. World Academy of Science, Engineering and Technology, vol. 5.

Marie, Edward, \& Prakash.(2007). Are Women More Risk-Averse Than Men? (online) (http://www.campus-for-finance.com. 
Masomi, S. R., \& Ghayekhloo, S. (2011). Consequences of human behaviors' in Economic: the Effects of Behavioral Faktors in Investment decision making at Tehran Stock Exchange. International Conference on Business and Economics Research.

Odean, T. (1999). Do Investor Trade Too Much. The American Economics Review, vol 89, (5), 1279-1298.

Odean, T. (2002). Volume, Volatility, Price and Profit When All Traders are Above Average. The Journal of Finance.

Pompian, M. M.( 2006). Behavioral Finance and Wealth Management: How to Build Optimal Portofolios That Account for Investor Biases. John Wiley \& Sons, Inc.

Ritter, J. R.( 2003). Behavioral Finance, Pasific-Basin Finance Journal Vol 11, 429-332.

Schaefer,S.P; Cristina, C.W; Adam, S. G; \& W. Keith .C. (2004). Overconfidence and the Big Five. Journal of Research in Personality. 38, 473-480.

Setiawati, D.( 2009). Perbedaan Komitmen Kerja Berdasarkan Orientasi Peran Gender. Depok: Universitas Gunadarma.

Stone, E. R., Dodrill, C. L., \& Johnso, N. (2011). Depressive Cognition: A Test of Depressive Realism Versus Negativity Using General Knowledge Questions. Journal of Personality, 135, 583-602.

Sutomo, Joandi. (2013). Apa yang Membuat Investor Overconfidence? Pada PT. Trijaya Pratama Futures Surabaya. Skripsi. Surabaya: Universitas Kristen Satya Wacana.

Trinugroho, I \& Sembel, R (2011). Overconvidence and Excessive Trading Behavior. International Journal of Business and Management, vol.6 (7), 147-152.

Trivers, R. (2000). The Elements of a Scientific Theory of Self-Deception. Annals NY acad Sciences 907: 114-131.

Zaidi, F. B. \& Tauni, M. Z. (2012). Influence of Investor's Personality traits and Demographics on Overconfidence Bias. Interdisiplinary Journal of Contemporary Research In Business, Vol. 4, No. 6 October 2012.

Venter, G. V. D., \& Michayluk, D.(2008). An Insight into Overconfidence in the Forecasting Abilities of Financial Advisors". Australian Journal of Management, Australian School of Business, vol. 32(3), 545-557.

Warren; R.E. Stevens \& C.W. McConkey. (1990). Using Demographic and Lifestyle Analysis to Segment Individual Investor. Financial Analysis Journal. 